Management and Financial Innovations, vol. 15, no. 4 (2018): 113-122.

DOI: http://dx.doi.org/10.21511/imfi.15(4).2018.09

Chuhunov, I. Ya. et al. Biudzhetno-podatkova polityka u systemi rehuliuvannia ekonomiky [Fiscal Policy in the System of Economic Regulation]. Kyiv: Hlobus-Press, 2018.

Chuhunov, I. Ya. et al. Derzhavne finansove rehuliuvannia ekonomichnykh peretvoren [State Financial Regulation of Economic Transformations]. Kyiv: Kyiv. nats. torh.ekon. un-t, 2015.

Chuhunov, I., and Makohon, V. "Biudzhetna stratehiia v umovakh ekonomichnykh peretvoren" [Budget Strategy in the Conditions of Economic Transformations]. Visnyk Kyivskoho natsionalnoho torhovelno-ekonomichnoho universytetu, no. 5 (2018): 5-18.

"Informatsiia pro vykonannia Derzhavnoho biudzhetu Ukrainy" [Information on the Execution of the State Budget of Ukraine]. Derzhavna kaznacheiska sluzhba Ukrainy. https://www.treasury.gov.ua/ua

Kyrylenko, O. P., and Vatslavskyi, O. I. "Biudzhetnyi kontrol pry planuvanni mistsevykh biudzhetiv" [Budget Control when Planning Local Budgets]. Svit finan- siv. 2018. http://sf.tneu.edu.ua/index.php/sf/article/ view/1067/1072

Lysiak, L. V., and Kushnir, A. I. "Finansova stiikist mistsevykh biudzhetiv: teoretychnyi aspekt" [Financial Stability of Local Budgets: Theoretical Aspects]. Molodyi vchenyi, no. 1 (2) (2019): 472-475.

DOl: https://doi.org/10.32839/2304-5809/2019-1-65-109

Revelli, F., and Zotti, R. "The Sacred and the Profane of Budget Cycles: Evidence from Italian Municipalities". International Tax and Public Finance. 2019. https:// editorialexpress.com/cgi-bin/conference/download. cgi?db_name $=$ SIEP2018\&paper_id $=132$

"Statystychna informatsiia Derzhavnoi sluzhby statystyky Ukrainy" [Statistical Information of the State Statistics Service of Ukraine]. http://www.ukrstat.gov.ua/

Segura III, J. "The effect of state and local taxes on economic growth: A spatial dynamic panel approach". Papers in Regional Science, vol. 96, no. 3 (2017): 627-645.

DOI: https://doi.org/10.1111/pirs.12221

Sidenko, V. R. et al. Instytutsiina transformatsiia finansovoekonomichnoi systemy Ukrainy $v$ umovakh hlobalizatsii [Institutional Transformation of the Financial and Economic System of Ukraine in the Context of Globalization]. Kyiv: Kyiv. nats. torh.-ekon. un-t, 2017.

\title{
ANALYSIS OF THE GLOBAL PRINCIPLES OF PERSONAL INCOME TAXATION
}

\author{
${ }^{\odot 2020}$ OLEKSICH Z. A., NAUMENKO R. 0.
}

UDC 336.226.11(477)

JEL: H22; H24

Oleksich Z. A., Naumenko R. O. Analysis of the Global Principles of Personal Income Taxation

This article is aimed at researching the system of taxation of personal income in Ukraine and the world, as well as a making forth a proposal to reform the existing system of taxation of personal income in Ukraine. The basics of taxation of personal income in the economically developed world countries, such as Germany, USA, France, Great Britain, and Poland, are analyzed. The carried out analysis displays the feasibility of reforming the current principles in the following directions: changing the taxation base in favor of the average household income; introduction of progressive taxation; introduction of a zero interest rate; focus on social justice by taking into account marital status and the presence of dependents; accounting for annual income. Taking into account the current status of the national economy, it can be noted that the thoughtless copying of the world experience of the tax model for the current realities of Ukrainian economy is untenable. At the same time, the experience of the high-income countries shows that such an approach should help to reduce income stratification. That is why it is advisable to introduce a proportional taxation system. Applying a moderate progressive scale of 10 to $40 \%$ would reduce the tax burden on the low-and middle-income taxpayers, and the introduction of a $0 \%$ rate would protect low-income citizens. With the introduction of the proportional rate, Ukraine will achieve the long-awaited balance between income, and, as a result, will increase revenues to the budget. At the same time, reducing the tax burden on the low-and middle-income citizens should solve the problem of shadow wages, as the amount of taxes will decrease and the social guarantees for workers will remain. The experience analyzed demonstrates the efficiency of the proposed steps and proves the need for the specified reforms, providing vivid examples of the results of such changes.

Keywords: system of taxation, personal income tax, progressive taxation, progressive tax rate.

DOI: https://doi.org/10.32983/2222-4459-2020-3-336-344

Fig.: 2. Tabl.: 8. Formulae: 2. Bibl.: 14.

Oleksich Zhanna A. - PhD (Economics), Assistant of the Department of Accounting and Taxation, Education and Research Institute for Business Technologies "UAB» of the Sumy State University (57 Petropavlivska Str., Sumy, 40000, Ukraine)

E-mail: z.oleksich@uabs.sumdu.edu.ua

ORCID: https://orcid.org/0000-0002-4486-974X

Naumenko Roman 0. - Student, Education and Research Institute for Business Technologies «UAB» of the Sumy State University (57 Petropavlivska Str., Sumy, 40000, Ukraine)

E-mail: Romasonn@gmail.com

УДК 336.226.11(477)

JEL: H22; H24

Олексіч Ж. А., Науменко Р. О. Аналіз світових засад оподаткування доходів фізичних осіб

Метою даної статті є дослідження системи оподаткування доходів фізичних осіб в Україні та світі, а також пропозиція щодо реформування існуючої системи оподаткування доходів фізичних осіб в Україні. Проаналізовано засади оподаткування доходів фізичних осіб в економічно розвинутих країнах світу, таких як: Німеччина, Сполучені Штати Америки, Франція, Великобританія, а також у Польщі. Проведений аналіз засвідчив доцільність ресормування поточних засад у таких напрямах: зміна бази оподаткування на користь середнього доходу родини; впровадження про- 
гресивного оподаткування; запровадження нульової процентної ставки; орієнтація на соціальну справедливість за рахунок урахування сімейного стану та наявності утриманців; урахування річного доходу. Беручи до уваги сучасний стан вітчизняної економіки, можна зазначити, що бездумне копіювання світового досвіду податкової моделі на сьогоднішні реалії української економіки не є виправданим. Водночас досвід держав з високим рівнем розвитку економіки свідчить, що такий підхід має сприяти зменшенню розшарування населення за рівнем доходів. Саме тому доцільно ввести пропориійну систему оподаткування. Застосування помірних ставок прогресивної шкали від 10 до $40 \%$ зменшить податкове навантаження на платників податків із низьким і середнім рівнем доходів, а введення ставки 0\% надасть змогу захистити малозабезпечених громадян. Із запровадженням пропориійної ставки в Україні буде досягнутий довгоочікуваний баланс між доходами, а, як результат, будуть збільшені надходження до бюджету. Разом із цим зменшення податкового навантаження на громадян з низьким і середнім доходом повинно вирішити проблему тіньових заробітних плат, оскільки суми податків зменшиться, а соціальні гарантії для робітників залишаться. Проаналізований досвід засвідчує ефективність запропонованих кроків та доводить необхідність проведення зазначених ресрорм з яскравими прикладами результатів таких змін. Ключові слова: система оподаткування, податок на доходи фізичних осіб, прогресивне оподаткування, прогресивна ставка податку.

Рис.: 2. Табл.: 8. Формул: 2. Бібл.: 14.

Олексіч Жанна Анатоліївна - кандидат економічних наук, асистент кафедри бухгалтерського обліку та оподаткування, Науково-навчальний інститут бізнес-технологій «УАБС» Сумського державного університету (вул. Петропавлівська, 57, Суми, 40000, Україна)

E-mail: z.oleksich@uabs.sumdu.edu.ua

ORCID: https://orcid.org/0000-0002-4486-974X

Науменко Роман Олегович - студент, Науково-навчальний інститут бізнес-технологій «УАБС» Сумського державного університету (вул. Петропавлівська, 57, Суми, 40000, україна)

E-mail: Romasonn@gmail.com

УДК 336.226.11(477)

JEL: H22; H24

\section{Олексич Ж. А., Науменко Р. О. Анализ мировых принципов налогообложения доходов физических лиц}

Целью данной статьи является исследование системы налогообложения доходов физических лиц в Украине и мире, а также предложение по реформированию существующей системы налогообложения доходов физических лиц в Украине. Проанализированы основы налогообложения доходов физических лиц в экономически развитых странах мира, таких как: Германия, США, Франция, Великобритания, а также Польши. Проведенный анализ показал целесообразность ресормирования текущих принципов по следующим направлениям: изменение базы налогообложения в пользу среднего дохода семьи; внедрение прогрессивного налогообложения; введение нулевой процентной ставки; ориентация на социальную справедливость за счет учета семейного положения и наличия иждивенцев; учет годового дохода. Принимая во внимание современное состояние отечественной экономики, можно отметить, что бездумное копирование мирового опыта налоговой модели на сегодняшние реалии украинской экономики является неоправданным. В то же время опыт государств с высоким уровнем развития экономики свидетельствует, что такой подход должен способствовать уменьшению расслоения населения по уровню доходов. Именно поэтому челесообразно ввести пропорциональную систему налогообложения. Применение умеренных ставок прогрессивной шкалы от 10 до 40\% уменьшит налоговую нагрузку на налогоплательщиков с низким и средним уровнем доходов, а введение ставки 0\% позволит защитить малообеспеченных граждан. Свведением пропорциональной ставки в Украине будет достигнут долгожданный баланс между доходами, a, как результат, будут увеличены поступления в бюджет. Вместе с этим уменьшение налоговой нагрузки на граждан с низким и средним доходом должно решить проблему теневых заработных плат, поскольку суммы налогов уменьшатся, а социальные гарантии для работников останутся. Проанализированный опыт свидетельствует об эффрективности предложенных шагов и доказывает необходимость проведения указанных реформ с яркими примерами результатов таких изменений.

Ключевые слова: система налогообложения, налог на доходы физических лиц, прогрессивное налогообложение, прогрессивная ставка налога.

Рис.: 2. Табл.: 8. Формул: 2. Библ.: 14.

Олексич Жанна Анатольевна - кандидат экономических наук, ассистент кафедры бухгалтерского учета и налогообложения, учебно-научный институт бизнес-технологий «УАБД» Сумского государственного университета (ул. Петропавловская, 57, Сумы, 40000, Украина)

E-mail: z.oleksich@uabs.sumdu.edu.ua

ORCID: https://orcid.org/0000-0002-4486-974X

Науменко Роман Олегович - студент, Учебно-научный институт бизнес-технологий «УАБД» Сумского государственного университета (ул. Петропавловская, 57, Сумы, 40000, Украина)

E-mail: Romasonn@gmail.com

$\mathrm{T}$ he key component of the tax system is the personal income tax. Global experience shows that taxation of income is an effective redistribution instrument in a market economy with clearly defined terms of a social contract that can provide a high standard of living and income [1].

Currently, in the context of reduced production, even if unemployment and wage arrears are reduced, the need to support social justice at the state level remains essential [2-4]. This is due to the fact that even in the context of positive general trends these indicators of unemployment and debt remain quite high. In such circumstances, redistribution through taxation should satisfy the existing need to review the principles of redistribution of income in society [3; 4].

In times of constant change and transformation of the economy, the problem of improving the personal income tax requires constant analysis and study by scientists. This problem was considered in works of a number Ukrainian scientists, namely: P. K. Bechko, L. M. Demidenko, N. M. Kostina, P. A. Leshchuk, O. V. Lyubinets, V. M. Chubatyuk, K. I. Shvabi.

The purpose of this article is to analyze the global principles of taxation of the personal income.

State tax policy is expressed through a tax collection system that must comply with scientifically sound 
principles. In the realities of development and transformation of the economy of Ukraine, an important place is occupied by state regulation of financial and economic activity of business entities and incomes of citizens. The relevance of this topic is due to the fact that the personal income tax (hereinafter, PIT) is one of the main budgetforming taxes, and, therefore, its proper accounting and reporting, given the constant change of legislation, is a very important aspect in activity of the tax system.

Since in different countries the personal income tax has different names (federal income tax, income tax), then we will use the PIT as the general name of the tax.

The system of accounting, accrual and payment of PIT in Ukraine is not perfect, which leads to the emergence of hidden revenues.

Tax reforming is considered in the following aspects:

+ taxation of citizens' income should be progressive or proportionate;

+ what progression rates or what proportionate tax rates to apply;

+ the possibility of applying a single tax rate;

+ what should be the basis of taxation, i. e., what to consider as income and what to tax.

$T^{n}$ n Ukraine, the procedure for taxation of personal income from January 1, 2013 is governed by Section IV of the Tax Code of Ukraine. If wages $>2940$ hryvnia, the PIT calculation formula will look like this:

$$
\text { PIT }=\text { wage } \times 18 \% \text {. }
$$

In most cases, the tax social privilege (hereinafter referred to as TSP) is not applicable since for 2020 the minimum wage is UAH4723, and the marginal income for applying TSP for 2020 is UAH2940, which indicates that there is no social justice in the tax.

The PIT is deducted from the amount of accrued income. That is, an individual receives the amount of income reduced by the amount of the PIT and military tax.

This formula calculates the personal income tax deducted by the tax agent from the paid (accrued) income in the form of salary or other payments equal to it.

The personal income tax rate shall be $18 \%$ of the tax base for income collected (paid, provided) (except for the cases specified in clauses 167.2-167.5 of the tax code of Ukraine), including but not exclusively in the form of payments: payments and remunerations charged (paid, provided) to the payer in connection with labor relations and civil contracts.

Taxation of income in the world has many examples of different systems. Among economically developed countries we will consider experience of Germany, Poland, USA, France, and Great Britain.

The taxation of personal income in Germany has a progressive system, which is a good example for other countries. Tax rates depend on various factors, such as:
+ the marital staus of the taxpayer (allows to rank the income of one person or the whole family);

+ the presence and number of children the payer has;

+ living alone or as a couple.

B ased on this, each taxpayer is provided with one of 6 groups, which determines the possibility of obtaining a tax rebate. The PIT rate in Germany depends on income and ranges from 0 to $45 \%$ [5].

German income tax rates for 2020 are displayed in Tbl. 1 .

Table 1

The PIT rates in Germany in 2020

\begin{tabular}{|c|c|c|c|c|}
\hline \multicolumn{2}{|c|}{$\begin{array}{c}\text { Taxable income } \\
\text { range for single } \\
\text { taxpayers (EUR) }\end{array}$} & \multicolumn{2}{|c|}{$\begin{array}{c}\text { Taxable income } \\
\text { range for married } \\
\text { taxpayers (EUR) }\end{array}$} & \multirow{2}{*}{$\begin{array}{c}\text { Tax rate } \\
\text { (\%) }\end{array}$} \\
\hline Over & Not over & Over & Not over & \\
\hline 0 & 9408 & 0.00 & 18816 & 0 \\
\hline 9408 & 57051 & 18.816 & 114.102 & $\begin{array}{c}\text { Progressive } \\
\text { from } \\
14 \text { to } 4\end{array}$ \\
\hline 57051 & 270500 & 114.102 & 541.000 & 42 \\
\hline 270500 & $\infty$ & 541.000 & $\infty$ & 45 \\
\hline
\end{tabular}

At the same time, $5.5 \%$ of the solidarity tax and $8 \%$ or $9 \%$ of the church tax are deducted from the citizens' income in some regions. It is also important to note that the resident income tax comes from all sources, even from abroad.

Transformation of the tax system to the realities of the economy is a necessary step for the development of the country. That is why, at the end of 2019, taxation of personal income in Poland underwent some changes. Poland has a two-tier progressive tax system (2020 tax rates are given in Tbl. 2) [6].

Table 2

Income tax rates in Poland in $\mathbf{2 0 2 0}$

\begin{tabular}{|c|c|c|}
\hline \multicolumn{2}{|c|}{ Annual taxable income (PLN) } & \multirow{2}{*}{ Tax rate (\%) } \\
\hline Over & Not over & \\
\hline 0 & 85528 & $\begin{array}{c}17 \% \text { (of the base } \\
\text { less the amount } \\
\text { decreasing tax) }\end{array}$ \\
\hline 85528 & $\infty$ & 32 \\
\hline
\end{tabular}

The PIT rate in Poland is calculated on the basis of annual income, it is also important that the tax benefit is granted only if the income is up to PLN85528 per year and is calculated individually. The amount of the benefit decreases with increasing income and ranges from PLN0.01 to PLN1140 per month. In addition, a tax benefit is granted to a payer who has a child in the family, PLN1112 for the first and second, PLN2000 for the third 
child and PLN2700 for the fourth and each subsequent child per month. Changes in taxation in Poland in 2019 also affected the young population, so the population under 26 years of age do not have to pay the PIT.

A nother striking example of income tax is the United States system. In the current context, the most important of all sources of federal budget revenue is the personal income tax, which provides more than half of the total federal budget. According to the US tax system, individuals' income can be taxed separately for each individual citizen and for the family as a whole. Taxable income is taxed on a progressive scale. In this case, taxpayers are divided into four categories, which are taxed at the same rates but with different gradation of income. The tax rate ranges from $10 \%$ to $37 \%$. In recent years, there has been a tendency to increase the minimum of non-taxable income [7].

The taxpayer categories are divided into four groups of taxpayers:

+ single (or those who are not officially married);

+ head of household (a family member who officially has income);

+ married, pay the tax together;

+ married, pay the tax separately.

In accordance with these categories, US PIT rates in 2020 are as follows (Tbl. 3) [8].
A tax credit in the US in 2020 is granted to citizens who have children under the age of 17 or disabled family members. A child tax credit can be of up to USD2,000, with other members - up to USD500. But there is a limit that indicates that family income should not exceed USD400 thousand and for unmarried people USD200 thousand.

Also, for low-income households, there is a separate graduation tax credit for the number of children, with the income of the head of the household and the unmarried family not exceeding USD50,162 per year and the married couple paying a total tax of USD56,844 per year. One more picularity is that there are benefits for the divorced, but those who pay alimony, and tax credit programs to support children under the age of 13 .

$\mathrm{F}$ rance, as one of the most economically developed countries, has a tax system similar to that of the United States. Tax rates are progressive and decrease with a decrease in income. An interesting point is the existence of a $0 \%$ rate that socially equalizes lowincome citizens. The maximum tax rate is $45 \%$, but according to statistics from the Ministry of Economy and Finance of France, this rate is paid by about $1 \%$ of the citizens. Separate tax credit programs can be identified for the citizens who have child support that increase the income ranking, which leads to a reduction in tax or the need to pay it altogether since there is a $0 \%$ rate.

Table 3

US annual income tax rates in $\mathbf{2 0 2 0}$

\begin{tabular}{|c|c|c|c|c|c|c|c|c|}
\hline \multicolumn{2}{|c|}{ Single } & \multicolumn{2}{c|}{ Married, filing jointly } & \multicolumn{2}{c|}{$\begin{array}{c}\text { Married, filing } \\
\text { separately }\end{array}$} & \multicolumn{2}{c|}{ Head of household } & $\begin{array}{c}\text { Tax rate } \\
\text { (\%) }\end{array}$ \\
\hline Over & Not over & Over & Not over & Over & Not over & Over & Not over & 10 \\
\hline 0 & 9875 & 0 & 19750 & 0 & 9875 & 0 & 14100 & 12 \\
\hline 9876 & 40125 & 19751 & 80250 & 9876 & 40125 & 14101 & 53700 & 22 \\
\hline 40126 & 85525 & 80251 & 171050 & 40126 & 85525 & 53701 & 85500 & 24 \\
\hline 85526 & 163300 & 171051 & 326600 & 85526 & 163300 & 85501 & 163300 & 24 \\
\hline 163301 & 207350 & 326601 & 414700 & 163301 & 207350 & 163301 & 207350 & 32 \\
\hline 207351 & 518400 & 414701 & 622050 & 207351 & 518400 & 207351 & 518400 & 35 \\
\hline 518401 & $\infty$ & 622051 & $\infty$ & 518401 & $\infty$ & 518401 & $\infty$ & 37 \\
\hline
\end{tabular}

Accordingly, we can see that, when choosing a tax rate, the legislation already applies to families in which only one person works. The tax rates themselves are minimal for small annual incomes, which socially equalizes the low- and middle-income sections, while the high annual income pays between $32 \%$ and $37 \%$ of the tax. The tax payment system also has its own peculiarity, e. g., if you are single and your annual income is USD60 thousand then you pay $10 \%$ of the USD9,875 amount, from the second threshold of USD 30,250 you pay $12 \%$ of the tax, and the difference of USD19,875 will be taxed at a rate of $22 \%$. Thus, from USD60 thousand, you pay $15 \%$ tax, not $22 \%$, by category.
Also, there is an opportunity to pay the family income tax while dividing the total annual income by the number of members, which does not increase the tax burden. Detailed information on France PIT rates in 2020 is displayed in Tbl. 4.

So, we can see that if the annual income of a French citizen is less than EUR10,064, then he/she is generally tax exempt. Presently, e. g., when a family consists of two working people with their annual income of EUR48 thousand, the calculation will be as follows:

$$
\left(\frac{48000}{2}-10064\right) \cdot 14 \%=1951.04 \text {. }
$$


France PIT rates in 2020

\begin{tabular}{|c|c|c|}
\hline \multicolumn{2}{|c|}{ Annual taxable income (EUR) } & \multirow{2}{*}{ Tax rate (\%) } \\
\cline { 1 - 2 } Over & Not over & \\
\hline 0 & 10064 & 0 \\
\hline 10065 & 27794 & 14 \\
\hline 27795 & 74517 & 30 \\
\hline 74518 & 157806 & 41 \\
\hline 157807 & $\infty$ & 45 \\
\hline
\end{tabular}

EUR1951.04 is the amount of PIT that each family member has to pay. The total amount is EUR3902.08 euros, which is $8 \%$ of EUR48 thousand. This example shows that high rates of proportional taxation do not lead to an increase in the tax burden on the population but rather act as a mechanism for social equalization of income.

In addition to the standard rate, there is an additional income tax of more than EUR250 thousand. This is called "contribution exceptionnelle sur les hauts revenus" or "high income exceptional contribution". For the unmarried, it is $3 \%$ of income up to EUR500 thousand and $4 \%$ of income over EUR500 thousand. For people in marriage, 3\% of EUR500 thousand to EUR 1million and 4\% more than EUR1 million. The tax is levied after determining the net income at the ordinary rate, which reduces the number of its payers $[9 ; 10]$.

One of the oldest tax systems is the UK system. The personal income tax is about $65 \%$ of all direct taxes coming to the state budget. The peculiarity of taxing the income of citizens is that their income is divided into certain portions (tax schedule), which are taxed using a separate method [7].

The tax rate is proportional and depends on annual income (Tbl.5).

Table 5

The UK PIT tax rates in 2020, GDP

\begin{tabular}{|l|c|c|c|}
\hline \multirow{2}{*}{ Group } & \multicolumn{2}{|c|}{ Annual taxable income } & \multirow{2}{*}{ Tax rate (\%) } \\
\cline { 2 - 3 } & Over & Not over & \\
\hline $\begin{array}{l}\text { Personal } \\
\text { Allowance }\end{array}$ & 0 & 12500 & 0 \\
\hline Basic rate & 12501 & 50000 & 20 \\
\hline Higher rate & 50001 & 150000 & 40 \\
\hline $\begin{array}{l}\text { Additional } \\
\text { rate }\end{array}$ & 150001 & $\infty$ & 45 \\
\hline
\end{tabular}

Personal Allowance is a tax credit provided by the state, which, in turn, allows you to not pay tax with an annual income of up to GDP12,500 or to reduce taxable income by that amount. It should be noted that the tax benefit of GDP12,500 is reduced only after GDP100 thousand in annual income, for every GDP2 in earnings the benefit is reduced by GDP1.
Thus, with an annual income of GDP40 thousand, you pay $20 \%$ tax from GDP27,500, which is GDP5,500 or $13.75 \%$ of income. In this case, with an income of more than GDP125 thousand, you pay tax at the full rate of $45 \%$.

Separately in the UK tax system Scotland stands out, where there are some differences, the tax-free limit has the same amount and the number of rates levels increas. The PIT rates in Scotland are: 19\%; 20\%; 21\%; 41\%; $46 \%[11]$.

$\mathrm{H}$ aving analyzed the world experience, we can identify the following key factors that determine the system of taxation of personal income in ecomonically developed countries:

+ a progressive tax system as a key element of the system;

+ the tax is paid at rates proportional to the increase in income;

+ there is a limit that provides tax benefits to lowor middle-income populations;

+ the existence of a $0 \%$ rate for incomes below the minimum wage;

+ providing tax credits for the maintenance of children or unemployed people.

Based on the international experience and current state of the tax system, we can suggest our own progressive tax system for our country. The key points of the proposed tax system will be:

+ tax rates are based on the income level, starting with the minimum wage;

+ tax will be paid depending on income levels, which will reduce the burden on the middle-income population, but with the exception of $0 \%$;

+ the introduction of a $0 \%$ rate for income below the minimum wage will reduce the tax burden on people with a minimum income;

+ the tax social privilege, as an inactive tool in today's realities, will be replaced by a child support allowance for children under 18 years of age, disabled or inactive. This tax benefit will reduce the amount of taxable income by $0.5,0.5$ and 0.25 minimum wages, respectively. In case of the unemployed, privileges will be granted only in the absence of income from unemployment benefits;

+ as practice shows, developed countries use annual income as a tax base. In turn we believe that using annual income to measure tax rates is not possible because, given the constant transformation of Ukraine's economy and the inability to predict the state of the economy in the long run, it will lead to unfairly inflated or reduced tax revenues.

Thus, based on all of the above, we can suggest our own progressive scale of the PIT rates, which is presented in Tbl. 6 (where $\mathrm{X}$ is the minimum wage fixed in the budget for the current year). 
The suggested progressive system for the PIT

\begin{tabular}{|c|c|c|}
\hline Income levels, UAH & $\begin{array}{c}\text { Income levels where } \mathrm{X} \text { is the mini- } \\
\text { mum wage set for the budget year }\end{array}$ & Suggested PIT rate, $\%$ \\
\hline Income $<$ minimum wage & Income $<\mathrm{X}$ & 0 \\
\hline $4723-7085$ & $\mathrm{X}-1.5 \mathrm{X}$ & 10 \\
\hline $7086-14169$ & $1.5 \mathrm{X}-3 \mathrm{X}$ & 15 \\
\hline $14170-28338$ & $3 \mathrm{X}-6 \mathrm{X}$ & 18 \\
\hline $28339-47230$ & $6 \mathrm{X}-10 \mathrm{X}$ & 20 \\
\hline $47231-94460$ & $10 \mathrm{X}-20 \mathrm{X}$ & 25 \\
\hline $94461-236150$ & $20 \mathrm{X}-50 \mathrm{X}$ & 30 \\
\hline $236151>\infty$ & $50 \mathrm{X}>\infty$ & 40 \\
\hline
\end{tabular}

As the global experience of introducing a $0 \%$ rate for low income shows, it is a socially necessary aspect of improving the tax system. According to statistics for December 2019, 6.9\% of citizens have incomes below the minimum wage, which indicates an urgent need for state support for this category of citizens [12].

The suggested tax system with just seven levels will allow an even distribution of tax burden across all categories of the population. Thus, the introduction of a rate of $10 \%$ and $15 \%$ with a slight difference in income levels is necessary since, according to statistics, about $35 \%$ of the population receive income from the minimum wage of up to UAH7,000, which indicates the importance of support of this category of population by the state. The level of income which will be taxed at $15 \%$ is the average level of income across Ukraine in different regions, according to the data from the State Statistics Service for 2019. This category is about $35 \%$ of the population, so we consider the rate of $15 \%$ to be a necessary measure both for the implementation of budget plans and for equalization of income of the citizens.

A s a result, in 2019, we can see a significant increase in the average wage from 9,223 to 12,264 hryvnia (by $32 \%$ ). With such an increase we simultaneously saw a situation with the devaluation of hryvnia by $19 \%$, which indicates the prospects for an increase in the average wage in 2020. For these reasons, the introduction of a $20 \%$ rate, in the long term, provides the budget with additional resources to cover underperforming funds in lower-income budgets. Also, it should be noted that only about $12.7 \%$ of citizens have an income of more than UAH20 thousand, with only $30 \%$ being employed in such fields as public administration and defense, financial and insurance activities, IT and air transportation, where average salaries exceed UAH20 thousand.

Particularly acute is the issue of salaries of top officials, who, according to published data, are paid more than UAH1million. In this case, we consider it necessary to distribute the income at the rate of $30 \%$ as significant, and starting from UAH23 6151 as over large using the proportional system of payment at the rate of $40 \%$ [13].
$\mathrm{T}$ hus, we can obtain a socially equal tax system that, according to the European principles, socially protects both the poor and the middle class, while increasing the tax burden on incomes of rich citizens.

Consider a typical situation using the proposed tax system and a progressive rate. The family consists of a working husband, a non-working wife and two children under 18 years of age. The monthly income is UAH20 000 .

$T S P=4723 \cdot(0.5+0.5+0.25)=5903.75$.

The tax base $=20000-5903.75=14096.25$.

PIT payable $=(14096.25-7085) \cdot 15 \%+7085 \cdot 10 \%=$

$$
=1760.19 \text {. }
$$

At $18 \%$ rate, the payment amount will be UAH3600.

Our progressive scale allows to address several issues at once. The first is to protect the poor from the heavy for them tax burden. Secondly, it is filling the budget by increasing the tax on wealthy people (Fig. 1, Fig. 2).

Having analyzed the data from the calculation in Tbl. 7 of the PIT payment from different incomes, we can conclude that the suggested progressive tax rate will allow the low- and middle-income population to reduce the tax burden and resolve the social inequality of their tax payment. It should be noted that the calculations did not take into account the possibility for certain categories of the population, the use of the tax privilege we suggested. Thus, we emphasize that there is more opportunity for low-income citizens to reduce the tax burden.

Regarding significant income, payments according to the proportional system, as we can see from thy example in Tbl. 7, are calculated not as a percentage but as a proportion of it. Thus, each group actually pays less than the specified percentage in its income category. This allows all categories of the population to fill the budget evenly, with citizens with higher incomes increasing their share in the total amount of PIT that will come to the budgets.

The comparison of the progressive tax system of the leading countries of the world and the one proposed by the authors is presented in Tbl. 8 . 


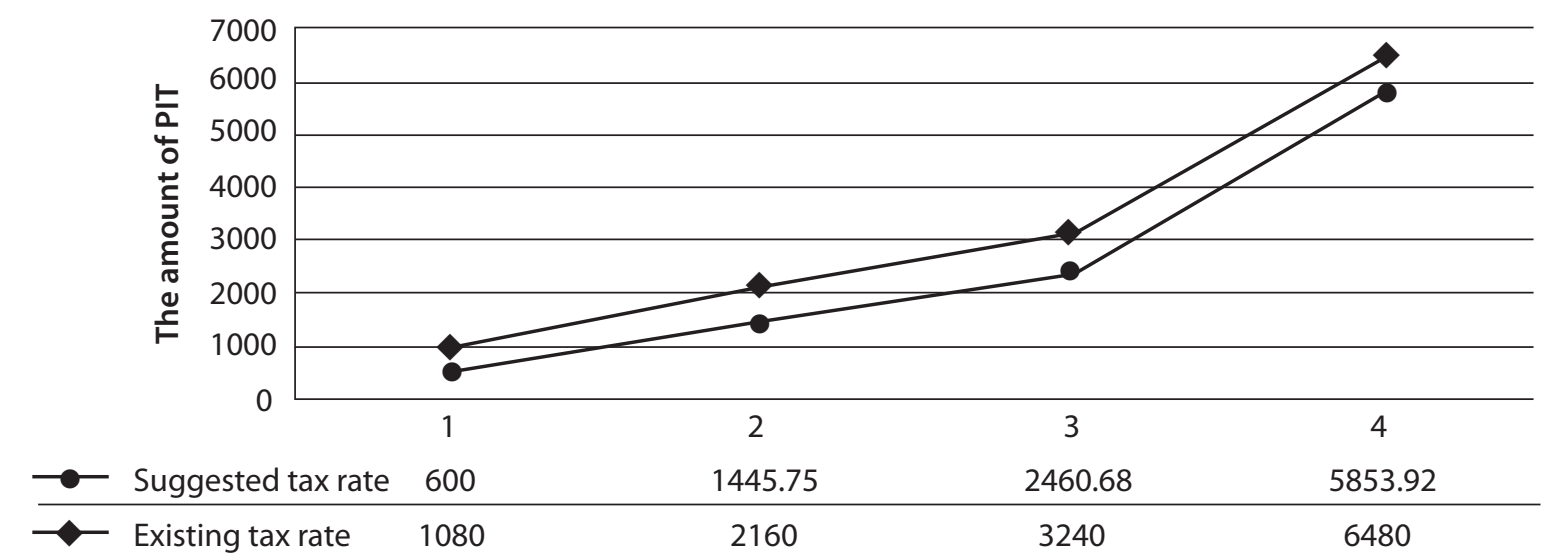

Fig. 1. Comparative payment schedule on PIT, with thew income of up to UAH50 thousand

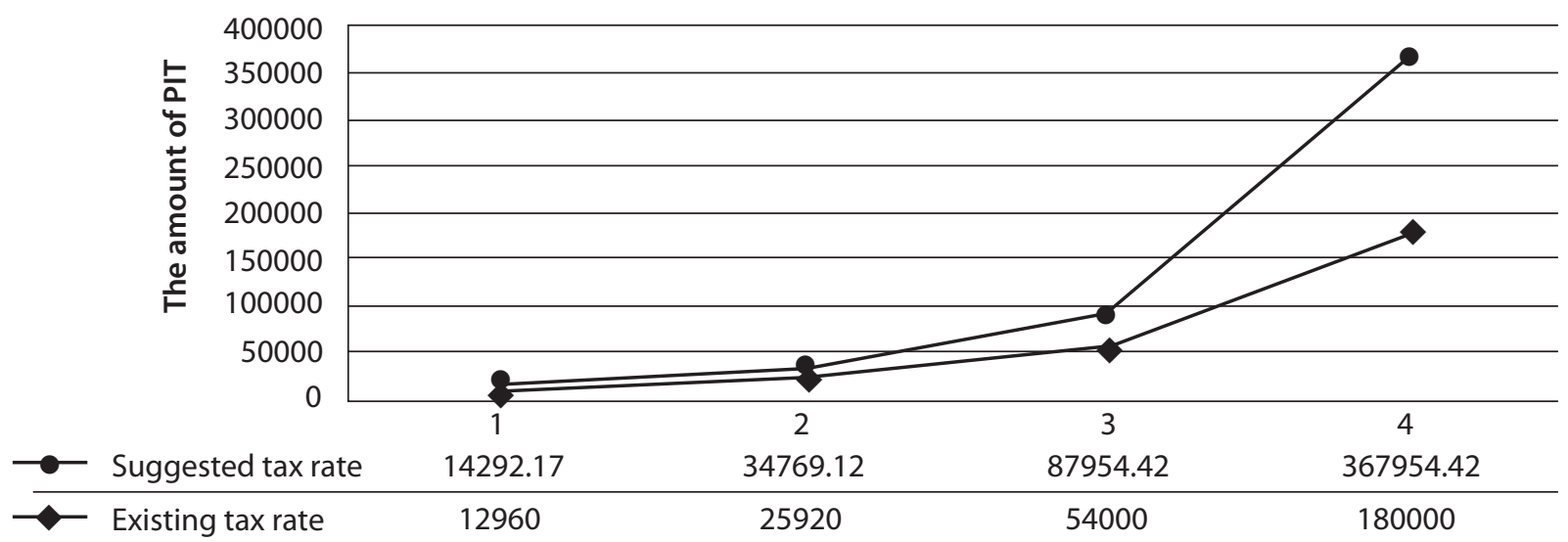

Fig. 2. Comparative chart of interest rates, with the income of over UAH50 thousand

Table 7

Example of calculating budget receipts from the PIT at the existing and proposed rate

\begin{tabular}{|c|c|c|c|}
\hline Income & $\begin{array}{c}\text { Suggested progressive tax } \\
\text { rate, \% }\end{array}$ & $\begin{array}{c}\text { Receipts at progressive tax } \\
\text { rate }\end{array}$ & $\begin{array}{c}\text { Receipts at existing tax } \\
\text { rate, 18\% }\end{array}$ \\
\hline 6000 & 10 & 600 & 1080 \\
\hline 12000 & 15 & 1445.75 & 2160 \\
\hline 18000 & 18 & 2460.68 & 3240 \\
\hline 36000 & 20 & 5853.92 & 6480 \\
\hline 72000 & 25 & 14292.17 & 12960 \\
\hline 144000 & 30 & 34769.12 & 25920 \\
\hline 300000 & 40 & 87954.42 & 54000 \\
\hline 1000000 & 40 & 367954.42 & 180000 \\
\hline Total amount: & - & 515330.48 & 285840 \\
\hline
\end{tabular}

$\mathrm{O}$ ne more important point is the existence of shadow wages. This issue is especially relevant for the medium and small income in Ukraine. Thus, P. K. Bechko in his work points out that the effective method for combating tax evasion is to use a system of control over the compliance of expenditures on consumption of natural persons to the level of their income, which is based on the use of indirect methods of assessing the income of the taxpayer based on their expenses and generalized indicators of lifestyle. The prototype for its formation may be the experience of France, where an extensive system of pre-selection of declarations of individuals for a more detailed verification is created. It is based on close cooperation between fiscal authorities, customs, gendarmerie, special services, as well as the largest state-owned companies - Gaz de France, Electricity de France,etc. Fiscal authorities have access to the commercial banks' information database, receiving infor- 
Comparison of progressive income tax systems of the leading countries of the world and the proposed tax system

\begin{tabular}{|l|c|c|c|c|}
\hline \multicolumn{1}{|c|}{ Country } & Minimum $\%$ & Max $\%$ & Number of levels & Existence 0\% \\
\hline Germany & 14 & 45 & 3 & Yes \\
\hline Poland & 17 & 32 & 2 & No \\
\hline USA & 10 & 37 & 7 & No \\
\hline France & 14 & 45 & 5 & Yes \\
\hline UK & 20 & 45 & 3 & Yes \\
\hline Ukraine* & 10 & 40 & 7 & Yes \\
\hline
\end{tabular}

Note: Ukraine * - the tax rate is the authors' development.

mation on all open accounts and transferring large sums of money. They have databases on all real estate transactions, vehicles, antiques, valuables and more. Such a system makes it possible, on the one hand, to deliberately identify alleged tax law offenders and candidates for enhanced scrutiny, and, on the other hand, it creates the preconditions for the inevitability of punishment for tax offenses [14].

At the same time, regarding the achievement of social equality with regard to the payment of the PIT, we suppose that the citizens with middle and low incomes will gradually leave the shadow market due to obtaining social guarantees, such as: sick leave, paid holidays, retirement, maternity leave and social security.

\section{CONCLUSIONS}

Taking into account the current state of the domestic economy, it can be noted that the thoughtless copying of the world experience of the tax model into the current realities of the Ukrainian economy is not appropriate. At the same time, the experience of countries with high levels of economic development shows that this approach should help reduce separation of the population by income level. The example of developed countries' tax systems indicates the need to change and introduce new taxation models.

In order to improve the quality of life of socially vulnerable groups, it is advisable to introduce a proportionate taxation system. Applying moderate progressive rates from $10 \%$ to $40 \%$ will reduce the tax burden on low- and middle-income taxpayers, while introducing a $0 \%$ rate will help protect those in need. At present, the fiscal potential of taxation of individual income is realized only partially, but using a progrresive rate in the country will help achieve a long-lasting balance between incomes and, as a result, increase in budget revenues. At the same time, lowering the tax burden on low- and middle-income citizens should solve the problem of shadow wages, as taxes will be reduced and social guarantees for workers will remain.

\section{LITERATURE}

1. Волкова О. В. Міжнародний досвід оподаткування доходів громадян в контексті сучасної податкової реформи в Україні. Бізнес-навігатор. 2014. № 3. C. 128-135. URL: http://www.mubip.org.ua/wpcontent/uploads/2015/11/244.pdf

2. Промисловість України у 2019 році // Економічний дискусійний клуб. 24.01.2020. URL: http://edclub. com.ua/analityka/promyslovist-ukrayiny-u-2019-roci

3. Заборгованість із виплати заробітної плати. Підсумок 2019 року // Економічний дискусійний клуб. 29.01.2020. URL: http://edclub.com.ua/ analityka/zaborgovanist-iz-vyplaty-zarobitnoyi-platypidsumok-2019-roku

4. Безробіття в україні та світі. I квартал 2019 року // Економічний дискусійний клуб. 25.09.2019. URL: http://edclub.com.ua/analityka/bezrobittya-vukrayini-ta-sviti-ii-kvartal-2019-roku

5. Bundeszentralamt für Steuern "BZSt" / Finanzvert waltung der Länder. URL: https://www.bzst.de/DE/ Service/Behoerdenwegweiser/FinanzverwaltungLaender/finanzverwaltunglaender_node.html

6. Ministerstwo Finansów. URL: https://www.gov.pl/ web/finanse

7. Шевченко Р. Ю. Розвиток оподаткування доходів фізичних осіб в умовах упровадження Податкового кодексу України. Наукові праці НДФІ. 2010. Вип. 4. C. 11-19.

8. An official website of the Internal Revenue Service (USA). URL: https://www.irs.gov/

9. Impots (France). URL: https://www.impots.gouv.fr/ portail/international?l=fr

10. An official website of the European Union. URL: https:// europa.eu/youreurope/

11. Direction générale des Finances publiques. URL: https://www.gov.uk/government/organisations/hmrevenue-customs

12. Державна служба статистики. URL: http://www. ukrstat.gov.ua/

13. Сайт Декларації. URL: https://declarations.com.ua/

14. Бечко П. К., Барабаш Л. В., Власюк С. А., Бондаренко Н. В. Напрями посилення соціальної спрямованості оподаткування доходів фізичних осіб в Україні. Фінансово-кредитна діяльність: проблеми теорії та практики. 2018. Т. 3. № 26. С. 452-461.

\section{REFERENCES}

An official website of the European Union. https://europa. eu/youreurope/

An official website of the Internal Revenue Service (USA). https://www.irs.gov/ 
"Bezrobittia v Ukraini ta sviti. I kvartal 2019 roku" [Unemployment in Ukraine and the World. And the Quarter of 2019]. Ekonomichnyi dyskusiinyi klub. September, 25. 2019. http://edclub.com.ua/analityka/bezrobittyav-ukrayini-ta-sviti-ii-kvartal-2019-roku

"Bundeszentralamt fur Steuern "BZSt"'. Finanzverwaltung der Lander. https://www.bzst.de/DE/Service/Behoerdenwegweiser/FinanzverwaltungLaender/finanzverwaltunglaender_node.html

Bechko, P. K. et al. "Napriamy posylennia sotsialnoi spriamovanosti opodatkuvannia dokhodiv fizychnykh osib v Ukraini" [Directions for Improving the Social Diversity of Income Taxation of Private Individuals in Ukraine]. Finansovo-kredytna diialnist: problemy teorii ta praktyky, vol. 3, no. 26 (2018): 452-461.

Derzhavna sluzhba statystyky. http://www.ukrstat.gov.ua/

Direction generale des Finances publiques. https://www. gov.uk/government/organisations/hm-revenue-customs

"Impots (France)". https://www.impots.gouv.fr/portail/ international? l=fr

Ministerstwo Finansow. https://www.gov.pl/web/finanse
"Promyslovist Ukrainy u 2019 rotsi" [Industry of Ukraine in 2019]. Ekonomichnyi dyskusiinyi klub. January, 24. 2020. http://edclub.com.ua/analityka/promyslovistukrayiny-u-2019-roci

Shevchenko, R. Yu. "Rozvytok opodatkuvannia dokhodiv fizychnykh osib v umovakh uprovadzhennia Podatkovoho kodeksu Ukrainy" [Development of Personal Income Taxation in the Context of the Implementation of the Tax Code of Ukraine]. Naukovi pratsi NDFI, no. 4 (2010): 11-19.

Sait Deklaratsii. https://declarations.com.ua/

Volkova, O. V. "Mizhnarodnyi dosvid opodatkuvannia dokhodiv hromadian v konteksti suchasnoi podatkovoi reformy v Ukraini“ [International Experience of Personal Income Taxation in the Context of Modern Tax Reform in Ukraine]. Biznes-navihator. 2014. http://www.mubip.org.ua/wp-content/uploads/2015/11/244.pdf

"Zaborhovanist iz vyplaty zarobitnoi platy. Pidsumok 2019 roku" [Wage Arrears. The Result of 2019]. Ekonomichnyi dyskusiinyi klub. January, 29. 2020. http://edclub. com.ua/analityka/zaborgovanist-iz-vyplaty-zarobitnoyi-platy-pidsumok-2019-roku

\section{АЛГОРИТМ ПОБУДОВИ СИСТЕМИ УПРАВЛІННЯ ФІНАНСАМИ НА ПІДПРИЕМСТВІ ๑2020 МАЛІКОВ В. В.}

УДК 336.6

JEL: D92; G32; 016

\section{Маліков В. В. Алгоритм побудови системи управління фінансами на підприємстві}

Основною проблемою управління фінансами в практичних умовах $є$ те, що через безліч наявного з цього питання матеріалу керівнику підприємства важко зрозуміти, з чого саме треба починати, яка інформація йому потрібна та на які показники (проблеми, явища) слід звертати увагу першочергово, а також яким чином все че пов'язано. Автор пропонує алгоритм побудови системи управління на підприємстві подати в такому вигляді: 1. Визначення фінансових цілей підприємства. 2. Виділення підсистем управління фінансами. 3. Визначення інформаційного забезпечення функціонування системи управління фінансами. 4. Визначення та дотримання правил управління фінансами. Для практичного застосування пропонується фінансові цілі підприємства навести у вигляді такої ієрархічної трирівневої моделі: основна ціль - отримання надлишкового грошового потоку; додаткові цілі - отримання прибутку та забезпечення платоспроможності підприємства; иілі розвитку - підвищення вартості підприємства та збільшення прибутку для його капіталізації. Виходячи зі сформульованих вище фінансових цілей пропонується виділити такі підсистеми управління фінансами: управління грошовими потоками; управління платоспроможністю; управління витратами, доходами і прибутком. Крім того, автор пропонує управлінські звіти умовно розділити на кілька рівнів (оперативний, тактичний і підсумковий) та виділити певні правила управління фінансами. Запропоновані рекомендації дозволять на практиці уникнути, зокрема, таких проблем, як виникнення касових розривів, ускладнення відносин з кредиторами тощо.

Ключові слова: управління, фінанси, платоспроможність, платежі, грошові потоки.

DOl: https://doi.org/10.32983/2222-4459-2020-3-344-348

Рис.: 2. Табл.: 2. Бібл.: 10.

Маліков Володимир Васильович - доктор наук з державного управління, профессор, професор кафредри управління та адміністрування, Харківський наиіональний автомобільно-дорожній університет (вул. Ярослава Мудрого, 25, Харків, 61002, Україна)

E-mail:yanaas@gmail.com

ORCID: https://orcid.org/0000-0002-6676-1799

УДК 336.6

JEL: D92; G32; 016

Маликов В. В. Алгоритм построения системы управления финансами на предприятии

Основной проблемой управления финансами в практических условиях является то, что из-за множества имеющегося по этому вопросу материала руководителю предприятия трудно понять, с чего надо начинать, какая информация ему нужна и на какие показатели (проблемы, явления) следует обращать внимание в первую очередь, а также каким образом всё это связано. Автор предлагает алгоритм построения системы управления на предприятии подать в следующем виде: 1. Определение финансовых иелей предприятия. 2. Выделение подсистем управления финансами. 3. Определение информационного обеспечения функционирования системы управления финансами. 4. Определение и соблюдение правил управления финансами. Для практического применения предлагается финансовые цели предприятия представить в виде следующей иерархической трехуровневой модели: основная цель - получение избыточного денежного потока; дополнительные цели - получение прибыли и обеспечение платежеспособности предприятия; цели развития - повышение стоимости предприятия и увеличения прибыли для её капита- 